\title{
Toxicity Evaluation and Antimicrobial Activity of Purified Pyocyanin from Pseudomonas aeruginosa
}

\author{
Mohamed N. F. Hamad ${ }^{1}$, Diaa A. Marrez ${ }^{2, *}$ (D), Sherien M. R. El-Sherbieny ${ }^{1}$ \\ 1 Dairy Department, Faculty of Agriculture, Damietta University, Damietta, Egypt \\ 2 Food Toxicology and Contaminants Department, National Research Centre, Cairo, Egypt \\ * Correspondence: diaamm80@hotmail.com;
}

Scopus Author ID 56288678900

Received: 16.04.2020; Revised: 25.05.2020; Accepted: 27.05.2020; Published: 1.06.2020

\begin{abstract}
Pigments from microbial sources considered a promising approach in food industry applications as a food colorant and biopreservatives agents. This study aims to evaluate the antimicrobial activity of purified pyocyanin against foodborne pathogens and study the safety of pyocyanin by toxicity determination. Purification and structure elucidation of pyocyanin was carried out using a UV-Vis spectrophotometer, Fourier Transform Infra-Red Spectroscopy (FTIR) and GC-MS analysis. Pyocyanin showed antibacterial activity against 9 species of foodborne pathogenic bacteria with a zone of inhibition from 10.8 to $22.6 \mathrm{~mm}$, and minimum inhibitory concentration (MIC) value ranged between 33.3 to $233.3 \mu \mathrm{g} \mathrm{ml}^{-1}$. Also, pyocyanin has antifungal activity against 10 mycotoxigenic fungi strains with inhibition zone value ranged from 7.0 to $17.6 \mathrm{~mm}$ and MIC value from 58.3 to 250 $\mu \mathrm{g} \mathrm{ml}^{-1}$. No toxicity was observed on shrimp nauplii up to $50 \mu \mathrm{g} \mathrm{ml}^{-1}$ for 12 and $24 \mathrm{~h}$ of exposure and up to $100 \mu \mathrm{g} \mathrm{ml}^{-1}$ for $12 \mathrm{~h}$. Also, no toxicity was recorded with pyocyanin using mouse bioassay up to $750 \mu \mathrm{g} \mathrm{ml}^{-1}$, while $1000 \mu \mathrm{g} \mathrm{ml}^{-1}$ observed toxicity equal to $3.28 \mathrm{MU}$ (mouse unit). Pyocyanin had antimicrobial activity against a wide range of foodborne pathogenic bacteria and mycotoxigenic fungi. Consequently, pyocyanin can be used as a cheap and safe source in the food industry and pharmaceutical applications.
\end{abstract}

Keywords: Pseudomonas aeruginosa; pyocyanin antimicrobial; toxicity evaluation.

(C) 2020 by the authors. This article is an open-access article distributed under the terms and conditions of the Creative Commons Attribution (CC BY) license (https://creativecommons.org/licenses/by/4.0/).

\section{Introduction}

The most common strategy for controlling food spoilage microorganisms is using chemical food preservatives with high efficiency against both foodborne pathogenic bacteria and mycotoxigenic fungi [1]. However, due to the growing concern about the potential human health risk, environmental contamination and development of foodborne pathogens resistance to these chemical food preservatives, a control strategy depended on food biopreservatives agents has become an alternative approach [2]. The biopreservatives agents have been successfully applied as a food additive to prevent the growth of foodborne pathogens for increasing the shelf life of food [3]. The use of microorganisms like bacteria, fungi, yeast, algae, and actinomycetes extracts as biopreservatives agents have been reported in several studies $[4,5]$.

Pseudomonas aeruginosa produces a wide variety of pigments as secondary metabolites. Four different major pigments of redox-active phenazine compounds that produce by $P$. aeruginosa, including pyocyanin, fluorescein, pyorubrin, and pyomelanin [6]. Pyocyanin is chloroform soluble blue-green pigment produce by an active culture of $P$. aeruginosa [7]. 
Fluorescein is water-soluble pigment with significant siderophore activity. Pyorubrin is irreversibly reduced to colorless form in reduced oxygen concentration, pyorubrin used as an antibacterial agent, and food colorants [8]. In addition to significant phenazine group, aeruginosin $\mathrm{A}$ and $\mathrm{B}$ were water-soluble red pigment, which produces by some $P$. aeruginosa with several biological activities [9].

Pyocyanin is an abroad spectrum pigment that has antibacterial activity against a wide range of drug-resistant bacteria and several species of foodborne pathogenic bacteria. Also, pyocyanin exhibited antifungal activity against different species of plant pathogenic fungi and mycotoxigenic fungi [6]. Furthermore, pyocyanin showed antioxidant and anticancer activity against several cancer cell lines [10]. So, the main objectives of this study are isolation, purification, and structure elucidation of pyocyanin from $P$. aeruginosa KT032066 strain. Toxicity evaluation of purified pyocyanin using brine shrimp assay and mouse bioassay. Finally, study the antimicrobial activity of pyocyanin against different strains of foodborne pathogenic bacteria and mycotoxigenic fungi.

\section{Materials and Methods}

\subsection{Bacterial strain.}

Pseudomonas aeruginosa KT032066 strain was acquired from Agriculture Microbiology Department, Agriculture and Biology Division, National Research Centre, Cairo, Egypt. P. aeruginosa Osh1 strain was cultivated in King's B (KB) g/l: Peptone 20 g, magnesium chloride $1.4 \mathrm{~g}$, potassium sulfate $10 \mathrm{~g}$, and distilled water 1 liter; $\mathrm{pH} 7.0 \pm 0.2,25^{\circ} \mathrm{C}$ ) as described by King et al. [11].

\subsection{Extraction and purification of pyocyanin from P. aeruginosa.}

A 24 hour of old culture broth was transferred into a $50 \mathrm{ml}$ centrifuge glass tube and centrifuged at $10,000 \mathrm{~g}$ for 20 minutes at $4^{\circ} \mathrm{C}$. The supernatant was transferred into a $500 \mathrm{ml}$ separating funnel and mixed with chloroform at a 1:1.5 ratio (supernatant: chloroform). This mixture was shaken well and kept undisturbed for 5-10 minutes for the pyocyanin fraction in the broth to get extracted to the chloroform layer.

The blue-colored chloroform layer, along with pyocyanin formed below the aqueous layer in the separating funnel, was collected into a covered conical flask to protect from light to prevent oxidation. This chloroform fraction was then transferred into a 500ml vacuum rotary flask and concentrated in a vacuum rotary evaporator at $40^{\circ} \mathrm{C}$.

\subsubsection{Silica gel column purification.}

The vacuum concentrated pyocyanin fraction was purified by silica gel column; silica gel absorbed crude pigment was loaded on column $(60 \mathrm{~cm}$ length and $3 \mathrm{~cm}$ diameter $)$. The column was packed with silica having a mesh size 100-200 and equilibrated using $1 \%$ chloroform-methanol solvent system in the ratio 1:1, and the concentrated pyocyanin fraction was loaded into the column. The purified pyocyanin was eluted with $15 \%$ methanol in chloroform. The blue-colored pyocyanin fraction was then collected into a $250 \mathrm{ml}$ conical flask, protected from light [12].

\subsubsection{Concentration of the purified pyocyanin.}

The column purified pyocyanin fraction $15 \%$ methanol in chloroform was further concentrated in a vacuum rotary evaporator at $40^{\circ} \mathrm{C}$. The concentrated pyocyanin was taken in 
a pre-weighed amber-colored bottle and passed through a jet of nitrogen gas to remove solvents and thoroughly dried. The weight of the dried pyocyanin was taken and subtracted from the weight of an empty bottle to get the dry weight of pyocyanin in milligrams. The concentrated and purified pyocyanin was collected in an amber-colored bottle and stored at $-20^{\circ} \mathrm{C}$ till use.

2.3. Structural elucidation and purity confirmation of pyocyanin.

\subsubsection{UV-Vis spectrophotometer.}

The purified pyocyanin was subjected to spectroscopic analysis. Ultraviolet and visible absorption spectra of purified pyocyanin dissolved in chloroform and $0.1 \mathrm{~N} \mathrm{HCl}$ were recorded over a range of $200-700 \mathrm{~nm}$. UV analysis was done using UV spectrophotometer (Shimadzu 1601, Japan). Absorbance maxima determined by UV spectrophotometric analysis [13].

\subsubsection{Fourier Transform Infra-Red Spectroscopy (FTIR).}

FTIR was employed to explore the functional groups and the chemical bonds in the present compound. The analysis was done using Jasco FTIR Spectrophotometer (FTIR-6100 Jasco, Japan) at National Research Centre. The sample was prepared by homogeneous dispersal of $1 \mathrm{mg}$ of pyocyanin extract in pellets of potassium bromide (Merck, USA). IR absorption spectra were obtained using a built-in plotter. IR spectra were collected over the range of 400$4000 \mathrm{~cm}^{-1}$ with a resolution of $4 \mathrm{~cm}^{-1}$. The spectrum was studied to interpret the chemical nature of the bioactive compound [14].

2.3.3. GC-MS analysis.

The GC/MS analysis was performed using a Thermo Scientific, Trace GC Ultra / ISQ Single Quadrupole MS, TG-5MS fused silica capillary column $(30 \mathrm{~m}, 0.251 \mathrm{~mm}, 0.1 \mathrm{~mm}$ film thickness). For GC/MS detection, an electron ionization system with ionization energy of 70 $\mathrm{eV}$ was used, Helium gas was used as the carrier gas at a constant flow rate of $1 \mathrm{ml} \mathrm{min}^{-1}$. The injector and MS transfer line temperature was set at $280^{\circ} \mathrm{C}$.

The oven temperature was programmed at an initial temperature of $50^{\circ} \mathrm{C}$ (hold $2 \mathrm{~min}$ ) to $150^{\circ} \mathrm{C}$ at an increasing rate of $7^{\circ} \mathrm{C} \mathrm{min}^{-1}$. Then to $270{ }^{\circ} \mathrm{C}$ at an increasing rate of $5^{\circ} \mathrm{C} \mathrm{min}^{-1}$ (hold $2 \mathrm{~min}$ ) then to 310 as a final temperature at an increasing rate of $3.5^{\circ} \mathrm{C} \mathrm{min}^{-1}$ (hold 10 $\min )$.

The quantification of all the identified components was investigated using a percent relative peak area. Tentative identification of the compounds was performed based on the comparison of their relative retention time and mass spectra with those of the NIST, WILLY library data of the GC/MS system.

\subsection{Antimicrobial activity of pyocyanin.}

\subsubsection{Test microorganisms.}

The inhibitory effect of pyocyanin extract was carried out on five species of pathogenic bacteria. Four Gram-positive bacteria (Bacillus cereus EMCC 1080, Staphylococcus aureus ATCC 13565, Staphylococcus sciuri 2-6 and Lactococcus lactis subsp. lactis) and five Gramnegative bacteria (Salmonella typhi ATCC 25566, S. enterica SA19992307, Escherichia coli 0157 H7 ATCC 51659, Pseudomonas fluorescens FP10 and Klebsiella pneumoniae LMD 7726). The stock cultures were grown on nutrient agar slant at $37^{\circ} \mathrm{C}$ for $24 \mathrm{~h}$ and then kept in the refrigerator until use. Ten fungal species were used for the antifungal assay, Aspergillus 
flavus NRRL 3357, A. parasiticus SSWT 2999, A. westerdijikia CCT 6795, A. styni IBT LKN 23096, A. ochraceus ITAL 14, A. niger IMI288550, A. carbonarus ITAL 204, Fusarium verticelloides ITEM 10027, F. proleferatum MPVP 328 and Penicillium verrucosum BFE 500. The stock cultures were grown on potato dextrose agar slant at $25^{\circ} \mathrm{C}$ for 5 days and then kept in the refrigerator until use.

\subsubsection{Disc diffusion technique.}

From the $24 \mathrm{~h}$ incubated nutrient agar slant of each bacterial species, a loop full of the microorganism was inoculated in a tube containing 4 to $5 \mathrm{ml}$ of tryptic soy broth. The broth culture is incubated at $35^{\circ} \mathrm{C}$ for $2-6 \mathrm{~h}$ until it achieves the turbidity of $0.5 \mathrm{McFarland}^{\mathrm{BaSO}_{4}}$ standards. The density of the turbidity standard was determined by using a spectrophotometer at $625 \mathrm{~nm}$. The absorbance at $625 \mathrm{~nm}$ should be $(0.008$ to 0.1$)$ for the 0.5 McFarland standards. BaSO4turbidity standard should be vigorously agitated on a mechanical vortex mixer before each use and inspected for a uniformly turbid appearance.

The sensitivity test of pyocyanin extract was determined with different bacterial cultures using the disc diffusion method by Kirby-Bauer technique [15,16]. Petri dishes were prepared with $20 \mathrm{ml}$ nutrient agar, and the bacterial cultures were uniformly from tryptic soy broth using cotton swabs. Pyocyanin extract was dissolved in $1 \mathrm{ml}$ of dimethyl sulfoxide (DMSO) to give $0.1,0.5,1.0,2.5$, and $5 \mathrm{mg} \mathrm{ml}^{-1}$ for pyocyanin. Sterilized discs $(6 \mathrm{~mm})$ from Whatman No. 1 filter paper were loaded by extract and entirely dried under sterile conditions. The discs were placed on the seeded plates by using a sterile forceps. DMSO represented as a negative control and tetracycline $\left(500 \mu \mathrm{g} \mathrm{ml}^{-1}\right)$ was used as a positive control. Plates were incubated at $37^{\circ} \mathrm{C}$ for $24 \mathrm{~h}$. The inhibition zones were measured and expressed as the diameter of the clear zone, including the diameter of the paper disc.

The fungal strains were plated onto potato dextrose agar (PDA) and incubated for 5 days at $25^{\circ} \mathrm{C}$. The spore suspension of each fungus was prepared in $0.01 \%$ Tween 80 solution. The fungal suspension was compared with the $0.5 \mathrm{McFarland}$ standard. Petri dishes of the YES medium were inoculated with $50 \mu \mathrm{l}$ of each fungal culture and uniformly spread using a sterile L- glass rod. Pyocyanin was loaded discs and placed on the seeded plates by using a sterile forceps. Negative control was prepared by using DMSO, and the commercial fungicide Nystatin (1000 Unit $\mathrm{ml}^{-1}$ ) was used as a positive control. Plates were incubated at $25^{\circ} \mathrm{C}$ for 24 - $48 \mathrm{~h}$. At the end of the period, antifungal activity was evaluated by measuring the zone of inhibition $(\mathrm{mm})$ against the tested fungus $[17,18]$.

\subsubsection{MIC of pyocyanin.}

The determination of minimum inhibitory concentration (MIC) was conducted using the tube dilution method $[19,20]$. A $24 \mathrm{~h}$ culture of the tested bacterial species was diluted in $10 \mathrm{ml}$ of tryptic soy broth (TSB) about the $0.5 \mathrm{McFarland}$ standard to achieve inocula of $10^{8}$ $\mathrm{CFU} \mathrm{ml}^{-1}$. In culture tube containing nine different concentrations of pyocyanin $(0.015,0.025$, $0.05,0.075,0.1,0.15,0.25,0.5,0.75$ and $1.0 \mathrm{mg} \mathrm{ml}^{-1}$ in DMSO) were prepared. Each tube was inoculated with $100 \mu \mathrm{l}$ of bacterial cell suspension and incubated at $37^{\circ} \mathrm{C}$ for $24 \mathrm{~h}$. The growth of the inoculum in broth is indicated by turbidity of the broth, and the lowest concentration of the extract, which inhibited the growth of the test organism, was taken as the minimum inhibitory concentration (MIC).

MIC against fungi was performed by using the technique of Perrucci et al. [21]. Different concentrations of pyocyanin were separately dissolved in $0.5 \mathrm{ml}$ of $0.1 \%$ Tween 80 
(Merck, Darmstadt, Germany), then mixed with $9.5 \mathrm{ml}$ of melting, $45^{\circ} \mathrm{C}, \mathrm{PDA}$, and poured into Petri dish $(6 \mathrm{~cm})$. The prepared plates were centrally inoculated with $3 \mu 1$ of fungal suspension. The plates were incubated at $25^{\circ} \mathrm{C}$ for $24-48 \mathrm{~h}$. At the end of the incubation period, mycelial growth was monitored, and the MIC was determined.

\subsection{Toxicity assessment of pyocyanin.}

\subsubsection{Brine shrimp bioassay.}

Toxicity of pyocyanin was tested using Artemia salina leach nauplii (Brine shrimp). Artemia salina was supplied by Avocet Artemin Inc., Utah, USA. Dried cysts were hatched ( $1 \mathrm{~g}$ cyst per liter) in filtered seawater at $27-30^{\circ} \mathrm{C}$ with strong aeration, under a continuous light regime. Approximately 12 hours after hatching, the phototrophic nauplii were collected with a pipette and concentrated in a small vial containing $5 \mathrm{ml}$ seawater. Each test consisted of exposing groups of 10 nauplii to various concentrations $(0,10,25,50,100,200,250,300,350$, $400,450,500,750$ and $1000 \mu \mathrm{g} \mathrm{ml}^{-1}$ ) of pyocyanin. The toxicity was determined after 12 and 24 hours of exposure by counting the number of survivors and calculating the percentage of mortality [22,23]. Larvae were considered dead if they did not exhibit any movement of appendages. All data were subjected to probit analysis using SPSS software.

\subsubsection{Mouse bioassay.}

Various concentrations $\left(100,250,300,350,400,450\right.$ and $\left.500 \mu \mathrm{g} \mathrm{ml}^{-1}\right)$ of pyocyanin were dissolved in 1:1 (w/v) 0.1 Molar acetic acid. To determine the dose-response curve, male Albino Swiss mice weighting $20 \pm 2 \mathrm{~g}$ were obtained from the Animal Housing Division, National Research Center, Cairo, Egypt. Potency was expressed as Mouse Units (MU), where $1 \mathrm{MU}$ is defined as the amount of toxins required for killing a $20 \mathrm{~g}$ mouse in 15 minutes. The survival time was measured from the completion of the intraperitoneal (i.p.) injection to the last breath [24]. Preliminary toxicity determination was performed using 3 mice for each sample preparation dose. Toxicity was observed, and death times were recorded.

\subsection{Statistical analysis}

Results were subjected to a one-way analysis of variance (ANOVA) of the general linear model (GLM) using the SAS statistical package. The results were the average of three replicates $(\mathrm{p} \leq 0.05)$.

\section{Results and Discussion}

\subsection{Purity confirmation of pyocyanin.}

Like most low molecular weight compounds, the crude pyocyanin from selected $P$. aeruginosa strain was purified using column chromatography. Ohfuji et al. [12] purified pyocyanin produced by $P$. aeruginosa using a silica gel column equilibrated with $1 \%$ methanol in chloroform. Pyocyanin was fractionated into yellow, red, and dark blow bands, a yellowgreen band tightly bound to stationary phase after elution with $15 \%$ methanol in chloroform. In contrast, blue band easily eluted as pure pyocyanin. 


\subsubsection{UV-Vis spectrophotometer.}

The absorbance spectrum of pyocyanin was monitored from 200 to $800 \mathrm{~nm}$ using a UVVis spectrophotometer (Figure 1). UV-visible spectroscopic analysis of purified pyocyanin showed two maxima at wavelengths $370 \mathrm{~nm}$ and $691 \mathrm{~nm}$. This peak, $370 \mathrm{~nm}$, indicates the presence of the pyocyanin compound. Parsons et al. [25] reported that pyocyanin was confirmed and quantitated by its characteristic absorption at 370 and $690 \mathrm{~nm}$. While, Priyaja [26] found that UV-visible spectroscopic analysis of purified pyocyanin observed four absorption maxima, at wavelengths of $699,529,310$ and $254.5 \mathrm{~nm}$ in the chloroform solvent and five absorption maxima in $0.1 \mathrm{~N} \mathrm{HCl}$ at wavelengths of 553, 390, 284, 246 and $246 \mathrm{~nm}$. This was comparable to the absorption maxima obtained by the pyocyanin standard at wavelengths such as 691, 529, 306, and $255.5 \mathrm{~nm}$ in chloroform and 555, 388, 284, 247 and $225 \mathrm{~nm}$ in $0.1 \mathrm{~N} \mathrm{HCl}$. On the other hand, Sudhakar et al. [27] indicated that the partially purified of pyocyanin was subjected to UV-spectrophotometer, and the absorbance of this solution was maximum at $278 \mathrm{~nm}$.

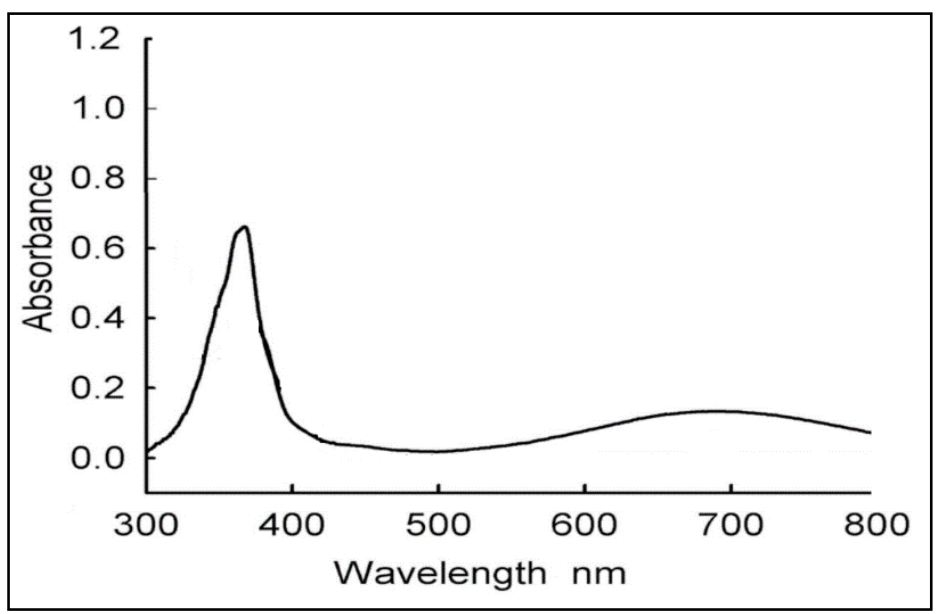

Figure 1. UV absorption spectra of pyocyanin.

\subsubsection{Fourier Transform Infra-Red Spectroscopy (FTIR).}

FTIR is the most preferred method of infrared spectroscopy. In infrared spectroscopy, IR radiation is passed through a sample. Some of the radiation is absorbed by the sample, and some of it is passed through (transmitted). The resulting spectrum represents the molecular absorption and transmission, which creates a molecular fingerprint of the sample. This is unique for every sample. This makes infrared spectroscopy useful for several types of analysis [14].

Further characterization of pyocyanin was by analyzing their IR spectrum. The pyocyanin spectrum in Figure (2) indicated the presence of phenazine as specified by side chains of the molecule. The peak at $3430.59 \mathrm{~cm}^{-1}$ shows the presence of O-H bond. The peak at $2365.26 \mathrm{~cm}^{-1}$ relates to the $\mathrm{C}$-Haromatic bond. The peak shown at $1633.41 \mathrm{~cm}^{-1}$ represents $\mathrm{C}=\mathrm{N}$ bond, and the peak at $1252.54 \mathrm{~cm}^{-1}$ corresponds to $\mathrm{C}-\mathrm{O}$ bond. This is comparable to the reports of standard FTIR spectra.

Pyocyanin was extracted using chloroform, and the presence of secondary metabolites were confirmed by the addition of $0.2 \mathrm{~N} \mathrm{HCl}$ partial purification of the pigment was carried out by column chromatography and subjected to UV-Vis spectrophotometer, and the structure elucidation of pyocyanin was done using ${ }^{1} \mathrm{H}$ NMR and FTIR [13,27]. Nansathit et al. [28] found that IR spectrum of pyocyanin showed bond at 3450 and $1557 \mathrm{~cm}^{-1}$ for N-H and the peak 
at $1971 \mathrm{~cm}^{-1}$ of $\mathrm{C}=\mathrm{O}$, characteristic of the amide group. For $\mathrm{C}=\mathrm{C}$ and $\mathrm{C}=\mathrm{N}$ were exhibited at the regions $1600-1400 \mathrm{~cm}^{-1}$. Peaks at $900-690 \mathrm{~cm}^{-1}$ were also presented $\mathrm{C}-\mathrm{H}$ of aromatic in the molecule. Laxmi and Bhat [29] reported that the pyocyanin FTIR spectrum showed peaks at $3448.59 \mathrm{~cm}^{-1}$ shows the presence of $\mathrm{O}-\mathrm{H}$ bond. The peak at $2951.18 \mathrm{~cm}^{-1}$ due to the CHaromatic bond and the peak shown at $1637.34 \mathrm{~cm}^{-1}$ represents $\mathrm{C}=\mathrm{N}$ bond, and the peak at $1307.02 \mathrm{~cm}^{-1}$ corresponds to $\mathrm{C}-\mathrm{O}$ bond.

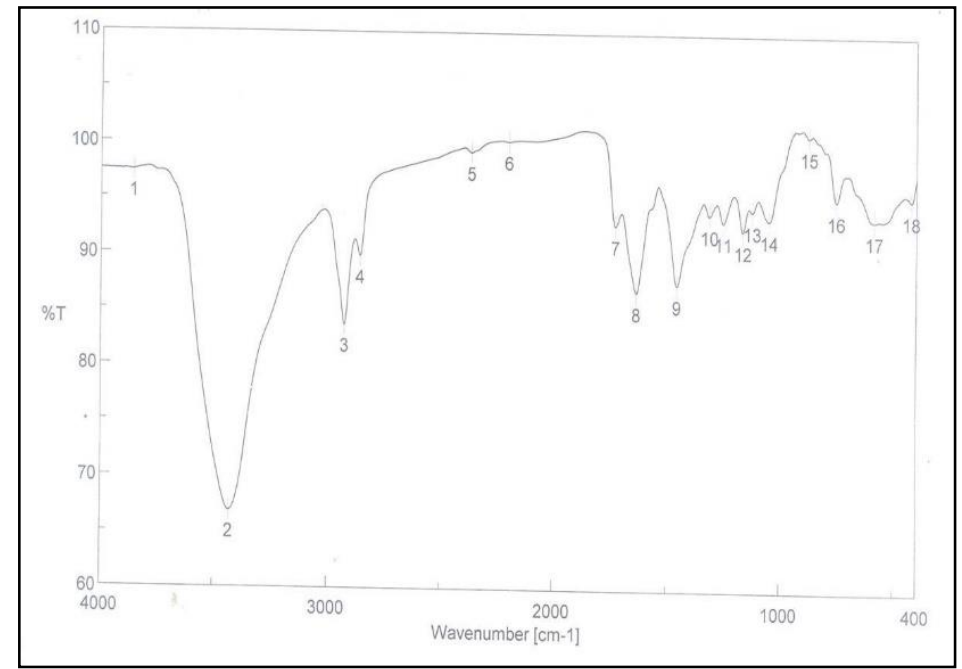

Figure 2. FTIR spectrum of pyocyanin produced by $P$. aeruginosa.

\subsubsection{GC-MS analysis.}

The GC-MS analysis of $P$. aeruginosa pigment showed that pyocyanin compound had retention time $53.08 \mathrm{~min}$ (Figure 3) and GC-MS spectrum (Figure 4) analysis revealed that the molecular weight 211 Dalton typical to as close as published for pyocyanin $\left(\mathrm{C}_{13} \mathrm{H}_{10} \mathrm{~N}_{2} \mathrm{O}\right)$ $[30,31]$.

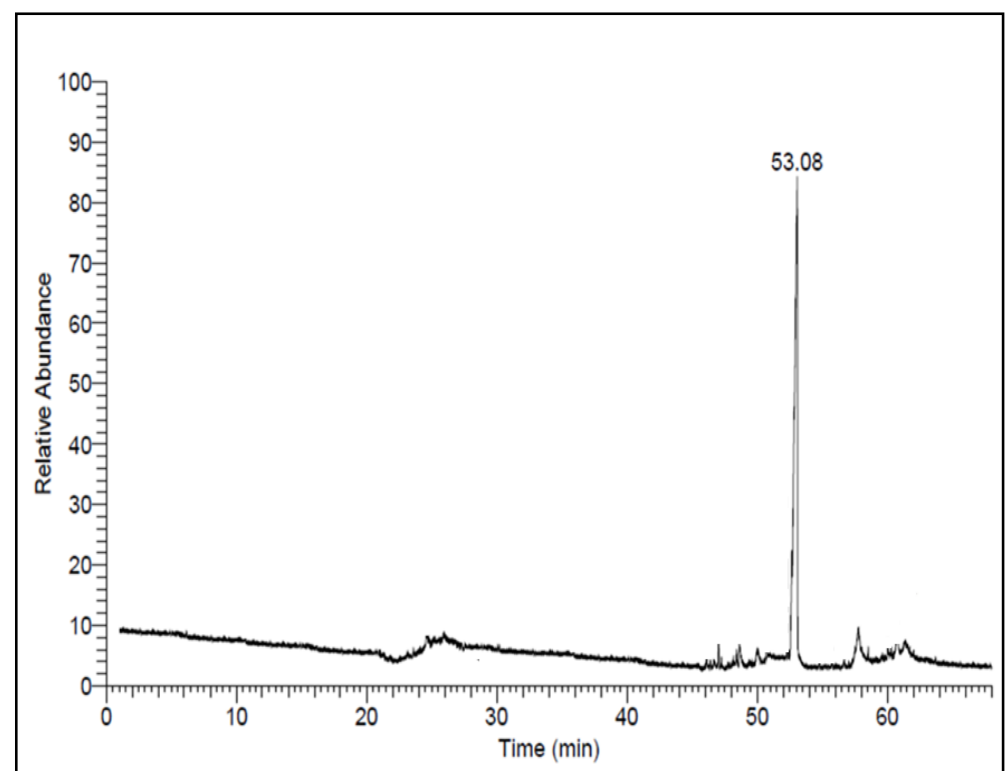

Figure 2. GC-MS chromatogram of pyocyanin produced by $P$. aeruginosa.

The results obtained were in agreement with results observed by Sudhakar et al. [27] they reported that the partially purified pyocyanin compound which was synthesized by $P$. aeruginosa and subjected to GC-MS which had the intense molecular ion at $\mathrm{m} / \mathrm{z} 210.23$ defining the molecular weight as 210 Dalton. 


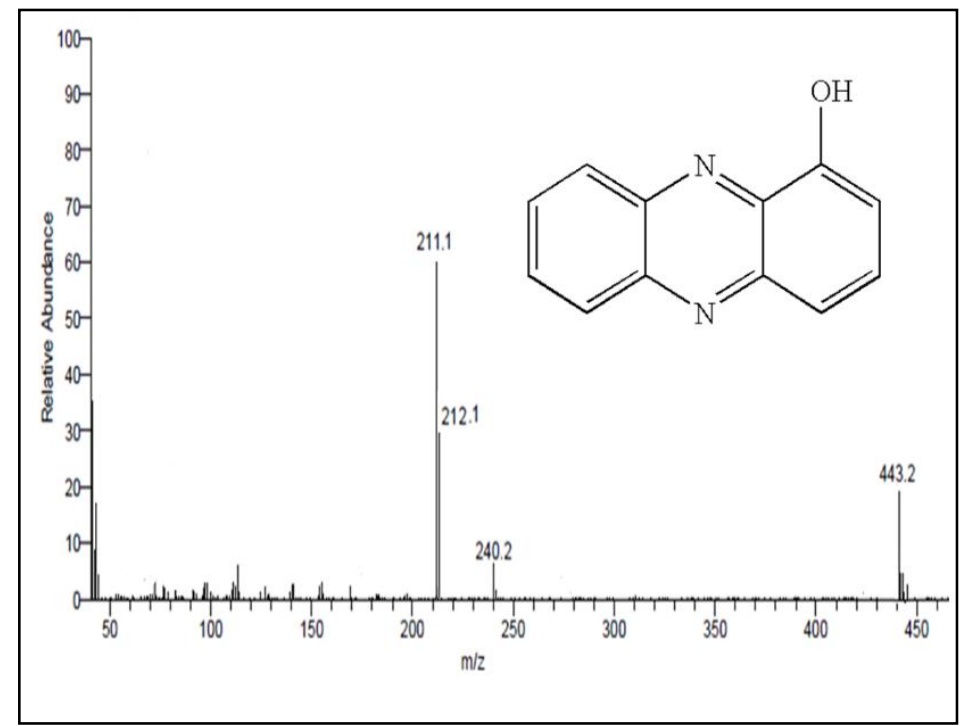

Figure 4. Chemical structure and GC-MS spectrum of pyocyanin.

The mass spectrum showed intense ions at $\mathrm{m} / \mathrm{z} 210$ and other ions125, 140, 168, 194, 181, 156, 108, and 92. Also, the spectrum was in agreement with pal and Revathi. [32]. The pyocyanin GC-MS was done, and the retention time was found at 11.04 mins. The molecular weight of the pyocyanin compound was about $210.23 \mathrm{kDa}$ [33]. Priyaja et al. [34] reported that mass spectroscopic analysis of the purified compound and pyocyanin standard demonstrated a protonated molecular ion at $\mathrm{m} / \mathrm{z} 211$ for confirmation of the purified pyocyanin compound.

\subsection{Antimicrobial activity of pyocyanin.}

\subsubsection{Antibacterial activity of pyocyanin.}

The antibacterial activities of different pyocyanin concentrations against 9 species of foodborne pathogenic bacteria are illustrated in (Table 1). All different concentrations of pyocyanin showed antibacterial activity against all tested bacteria ranged between 10.8 to 32.2 $\mathrm{mm}$ inhibition zones. The antibacterial activity of pyocyanin against tested bacteria increased by increasing of the pyocyanin concentrations $\left(0.1,0.5,1,2.5,5 \mathrm{mg} \mathrm{ml}^{-1}\right.$, respectively).

The inhibition zone of B. cereus ranged from 16.2 to $32.2 \mathrm{~mm}$, but the inhibition zone of Staph. aureus and Staph. sciuri ranged from 14.0 to 30.8 and 15.8 to $28.6 \mathrm{~mm}$, respectively. The antibacterial activity of pyocyanin against $E$. coli showed an inhibition zone increased by increasing in pyocyanin concentrations; it ranged from 16.8 to $26.7 \mathrm{~mm}$. The inhibition zones of $S$. typhi ranged from 14.7 to $31.6 \mathrm{~mm}$ and from 15.2 to $25.8 \mathrm{~mm}$ against $S$. entrica. However, the inhibition zone of pyocyanin against $P$. aeruginosa and $P$. fluorescens ranged between 12.7 $-22.6 \mathrm{~mm}$. Antibacterial activity of pyocyanin against $K$. pneumonia, and L. lactis showed zone of inhibition ranged from 10.8 to 26.0 and 11.1 to $18.3 \mathrm{~mm}$, respectively.

Pyocyanin at concentration $1 \mathrm{mg} \mathrm{ml}^{-1}$ showed antibacterial activity against $E$. coli higher than antibiotic standard, while required $2.5 \mathrm{mg} \mathrm{ml}^{-1}$ to observe activity higher than antibiotic standard against B. cereus, S. typhi, P. aeruginosa and K. pneumoniae. Whereas, it required5 $\mathrm{mg} \mathrm{ml}^{-1}$ of pyocyanin to showed antibacterial activity higher than tetracycline standard against $S$. aureus, S. sciuri, S. entrica, P. fluorescens, and L. lactis. The highest antibacterial activities were recorded against, B. cereus followed by $S$. typhi and S. aureus, which had inhibition zones $32.2,31.6$, and $30.8 \mathrm{~mm}$, respectively. 
Alzahrani and Alqahtani [35] indicated pyocyanin pigment of $P$. aeruginosa showed a greater effect against all Gram-positive and Gram-negative tested bacteria, and the antagonistic activity against tested bacteria increased by increasing of the pyocyanin pigment concentration. Also, El-Shouny et al. [36] found that the growth of all tested Gram-positive bacteria and Candida spp. were entirely inhibited by pyocyanin, whereas Gram-negative bacteria, including S. typhi and Pseudomonas mirabilis, were intermediately affected and K. pneumonia was resistant to pyocyanin. Saha et al. [37] reported that pyocyanin has antagonistic activity against pathogenic bacteria like Salmonella paratyphi, E. coli, and Klebsiella pneumonia. Rahman et al. [38] indicated that pyocyanin from P. aeruginosa DSO-129 has an antimicrobial effect on organisms like S. aureus, Staphylococcus epidermis, Bacillus subtilis, Micrococcus luteus and Saccharomyces cerevisiae.

Rane et al. [39] found that antimicrobial activity of the pyocyanin against strains of $B$. subtilis, C. albicans, and E. coli. El-fouly et al. [40] indicated that pyocyanin had high antimicrobial activity against $S$. aureus, E. coli, Klebsiella sp., S. typhi, Shigella sp. and $C$. albicans. Mathew et al. [41] found that pyocyanin had antibacterial activity against Bacillus thuringiensis, B. coagulans, B. subtilis, Staphylococcus aureus, and Pseudomonas fluorescence B21. However, no antimicrobial activity was noted against E. coli, $P$. aeruginosa SPC B 65 and P. fluorescens SPC B 60. Onbasli and Aslim [42] found that pyocyanin from Pseudomonas inhibits the E. coli isolates from sugar beet molasses.

\subsubsection{MIC of pyocyanin against foodborne pathogenic bacteria.}

As shown in Figure (5), the pyocyanin has a high antibacterial activity against all tested pathogenic strains and acts as a broad-spectrum antibiotic. The highest activity of pyocyanin was recorded against $S$. typhi with MIC value $21.7 \mu \mathrm{g} \mathrm{ml}^{-1}$, followed by B. cereus, Staph. sciuri, Staph. aureus and S. entrica with MIC values of 33.3, 41.7, 58.3, and $66.7 \mu \mathrm{g} \mathrm{ml}^{-1}$, respectively. Whereas, the lowest activity was showed against $K$. pneumoniae, L. lactis, and P. fluorescence with MIC values 183.4, 200, and $233.3 \mu \mathrm{g} \mathrm{ml}^{-1}$, respectively. Pyocyanin recorded the same MIC value $\left(91.7 \mu \mathrm{g} \mathrm{ml}^{-1}\right)$ against both $E$. coli and $P$. aeruginosa. Nowroozi et al. [43] revealed that the growth of $S$. aureus and E. coli were inhibited by the same concentration of pyocyanin with MIC value $56 \mu \mathrm{g} \mathrm{ml}^{-1}$.

\subsubsection{Antifungal activity of pyocyanin.}

Table 2 illustrates the antifungal activity of $P$. aeruginosa pyocyanin extract against different species of mycotoxigenic fungi. The highest antifungal activity of pyocyanin was shown against $A$. stynii followed by $F$. proliferatum and $A$. parasiticus with a zone of inhibition values $17.6,16.7$ and $16.5 \mathrm{~mm}$ at concentration $0.1 \mathrm{mg} \mathrm{ml}^{-1}$. The pyocyanin concentration 0.1 $\mathrm{mg} \mathrm{ml}^{-1}$ showed antifungal activity against $A$. flavus, $A$. carbonarus, $A$. stynii, $F$. verticelloides, $F$. proleferatum, and $P$. verrucosum with inhibition zone value ranged from 7.2 to $8.7 \mathrm{~mm}$, while A. parasiticus, A.niger, A. ochraceus, A. westerdijikia, and .F. proleferatum showed resistance. The negative control (DMSO) showed no inhibition whereas positive control, Nystatin at 1000 unit $\mathrm{ml}^{-1}$ showed inhibition of $12.8,16.0,15.8,15.4,13.2,15.4,16.6,11.5$, 13.5 and $15.8 \mathrm{~mm}$ against A. flavus, A. parasiticus, A. carbonarus, A. niger, A. stynii, A. ochraceus, $A$. westerdijikia, F. proliferatum, F. verticillioides and $P$. verrucosum, respectively. 
Table 1. Antibacterial activity of different concentrations of pyocyanin against different foodborne pathogenic bacteria species.

\begin{tabular}{|c|c|c|c|c|c|c|c|}
\hline \multirow[b]{2}{*}{ Bacteria } & \multicolumn{7}{|c|}{ Inhibition zone $\mathrm{mm}($ Mean $\pm *$ S.E) } \\
\hline & $\begin{array}{l}\text { Negative } \\
\text { control }\end{array}$ & $\begin{array}{l}\text { Positive } \\
\text { control }\end{array}$ & $5 \mathrm{mg} \mathrm{ml}^{-1}$ & $2.5 \mathrm{mg} \mathrm{ml}^{-1}$ & $1 \mathrm{mg} \mathrm{ml}^{-1}$ & $0.5 \mathrm{mg} \mathrm{ml}^{-1}$ & $0.1 \mathrm{mg} \mathrm{ml}_{1}^{-}$ \\
\hline B. cereus & 0 & $26.8 \pm 1.04^{\text {bc }}$ & $32.2 \pm 2.08^{\mathrm{a}}$ & $28.3 \pm 1.28^{\mathrm{b}}$ & $24.6 \pm 0.86^{\mathbf{c}}$ & $18.6 \pm 1.36^{\mathrm{d}}$ & $16.2 \pm 1.04^{\mathrm{e}}$ \\
\hline S. aureus & 0 & $25.7 \pm 0.58^{\mathbf{b}}$ & $30.8 \pm 2.14^{\mathrm{a}}$ & $25.6 \pm 1.60^{\mathbf{b}}$ & $22.6 \pm 2.04^{\mathrm{bc}}$ & $20.2 \pm 1.58^{\mathrm{c}}$ & $14.0 \pm 1.00^{\mathrm{d}}$ \\
\hline S. sciuri & 0 & $26.5 \pm 1.28^{\mathrm{ab}}$ & $28.6 \pm 0.76^{a}$ & $24.8 \pm 1.58^{\mathbf{b}}$ & $22.3 \pm 0.87^{\mathbf{c}}$ & $21.0 \pm 1.00^{\mathrm{c}}$ & $15.8 \pm 0.48^{\mathrm{d}}$ \\
\hline E. coli & 0 & $18.8 \pm 0.86^{\mathbf{c}}$ & $26.7 \pm 1.16^{\mathrm{a}}$ & $24.3 \pm 1.04^{\mathrm{a}}$ & $21.0 \pm 1.00^{\mathrm{b}}$ & $20.6 \pm 2.11^{b c}$ & $16.8 \pm 1.35^{\mathrm{d}}$ \\
\hline S. typhi & 0 & $25.4 \pm 2.02^{\mathrm{c}}$ & $31.6 \pm 2.14^{\mathrm{a}}$ & $30.5 \pm 1.00^{\mathbf{b}}$ & $25.8 \pm 1.58^{\mathrm{c}}$ & $22.0 \pm 1.00^{\mathrm{d}}$ & $14.7 \pm 0.86^{\mathrm{e}}$ \\
\hline S. enterica & 0 & $24.8 \pm 1.15^{\mathrm{ab}}$ & $25.8 \pm 1.36^{\mathrm{a}}$ & $24.2 \pm 1.21^{\mathrm{ab}}$ & $22.3 \pm 0.58^{\mathbf{b}}$ & $19.6 \pm 0.96^{\mathrm{c}}$ & $15.2 \pm 1.08^{\mathrm{d}}$ \\
\hline P. aeruginosa & 0 & $18.9 \pm 0.76^{\mathbf{b}}$ & $22.6 \pm 1.28^{\mathrm{a}}$ & $20.7 \pm 0.86^{\text {ab }}$ & $18.4 \pm 0.58^{b}$ & $16.8 \pm 0.78^{c}$ & $12.7 \pm 1.04^{\mathrm{d}}$ \\
\hline K. pneumoniae & 0 & $21.3 \pm 1.26^{\mathrm{c}}$ & $26.0 \pm 1.86^{\mathrm{a}}$ & $24.7 \pm 1.58^{\mathbf{b}}$ & $21.8 \pm 1.04^{\mathrm{c}}$ & $18.0 \pm 1.00^{\mathrm{d}}$ & $10.8 \pm 0.36^{\mathrm{e}}$ \\
\hline L. lactis & 0 & $18.5 \pm 1.16^{\mathrm{a}}$ & $18.3 \pm 0.76^{\mathbf{a}}$ & $16.0 \pm 1.00^{\mathbf{b}}$ & $14.6 \pm 1.14^{\mathrm{bc}}$ & $14.0 \pm 2.04^{\mathrm{c}}$ & $11.1 \pm 1.28^{\mathrm{d}}$ \\
\hline
\end{tabular}

$\mathrm{n}=3$, *S.E: standard error, different subscripts within the row are significantly different at the 5\% level, $0:$ No inhibition, negative control: DMSO, positive control: tetracycline.

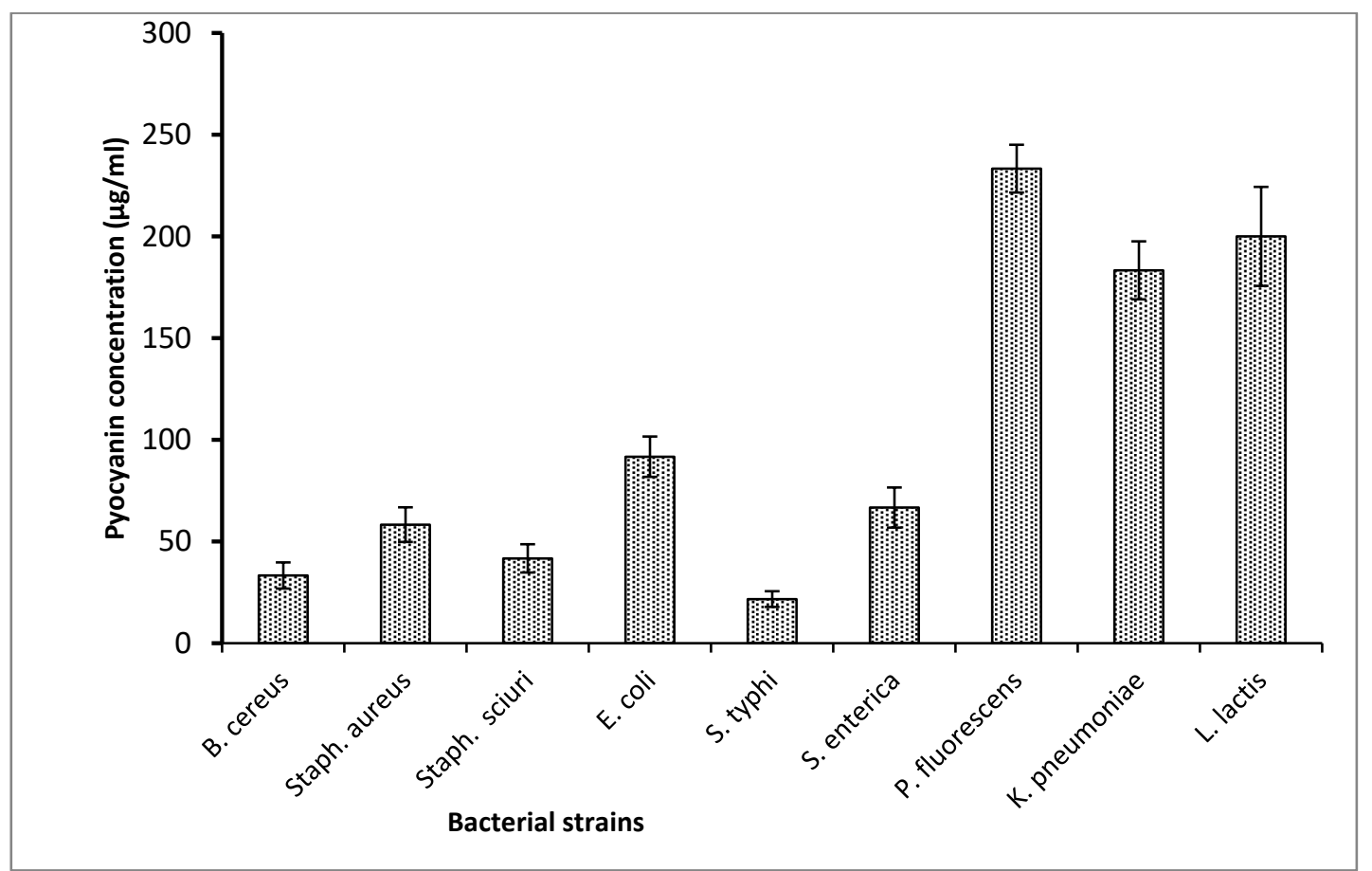

Figure 5. Minimum Inhibitory concentration of pyocyanin against different strains of foodborne pathogenic bacteria.

Wilson et al. [44] reported that pyocyanin, which is produced by $P$. aeruginosa, has the ability to disrupt the electron transport chain of fungi, and this reveals the antifungal effect. Kerr [45] reported that $P$. aeruginosa inhibited the growth of Candida albicans in vitro.

Table 2. Antifungal activity of different concentrations of pyocyanin against different mycotoxigenic fungi.

\begin{tabular}{|c|c|c|c|c|c|c|c|}
\hline \multirow[b]{2}{*}{ Fungi } & \multicolumn{7}{|c|}{ Inhibition zone mm (Mean $\pm *$ S.E) } \\
\hline & $\begin{array}{c}\text { Negative } \\
\text { control }\end{array}$ & $\begin{array}{c}\text { Positive } \\
\text { control }\end{array}$ & $5 \mathrm{mg} \mathrm{ml}^{-1}$ & $2.5 \mathrm{mg} \mathrm{ml}^{-1}$ & $1 \mathrm{mg} \mathrm{ml}^{-1}$ & $0.5 \mathrm{mg} \mathrm{ml}^{-1}$ & $0.1 \mathrm{mg} \mathrm{ml}^{-1}$ \\
\hline A. flavus & 0 & $12.8 \pm 0.86^{\mathbf{b}}$ & $14.8 \pm 1.28^{\mathrm{a}}$ & $11.2 \pm 1.12^{\mathrm{c}}$ & $8.2 \pm 0.36^{\mathrm{d}}$ & $8.0 \pm 1.00^{\mathrm{d}}$ & $7.2 \pm 0.58^{\mathrm{e}}$ \\
\hline A. parasiticus & 0 & $16.0 \pm 1.00^{\mathrm{a}}$ & $16.5 \pm 1.04^{\mathrm{a}}$ & $10.5 \pm 0.96^{\mathbf{b}}$ & $8.7 \pm 0.58^{c}$ & $7.5 \pm 0.21^{\mathrm{d}}$ & 0 \\
\hline A. carbonarus & 0 & $15.8 \pm 0.48^{\mathrm{a}}$ & $12.6 \pm 0.86^{\mathbf{b}}$ & $12.0 \pm 1.00^{\mathbf{b c}}$ & $11.8 \pm 1.11^{\mathrm{c}}$ & $10.3 \pm 1.21^{\mathrm{d}}$ & $7.6 \pm 0.67^{\mathrm{e}}$ \\
\hline A.niger & 0 & $15.4 \pm 0.76^{\mathrm{a}}$ & $11.8 \pm 0.75^{\mathbf{b}}$ & $9.5 \pm 0.32^{\mathrm{c}}$ & $8.7 \pm 0.86^{\mathrm{cd}}$ & $8.0 \pm 1.00^{\mathrm{d}}$ & 0 \\
\hline A. stynii & 0 & $13.2 \pm 0.36^{\mathbf{b c}}$ & $17.6 \pm 1.58^{\mathrm{a}}$ & $14.2 \pm 1.08^{\mathbf{b}}$ & $12.6 \pm 0.58^{c}$ & $12.0 \pm 1.00^{\mathrm{c}}$ & $8.7 \pm 0.48^{d}$ \\
\hline A. ochraceus & 0 & $15.4 \pm 1.04^{\mathrm{a}}$ & $10.8 \pm 0.48^{\mathbf{b}}$ & $9.7 \pm 1.14^{\mathrm{c}}$ & $7.8 \pm 0.21^{\mathrm{d}}$ & $7.0 \pm 0.50^{\mathrm{d}}$ & 0 \\
\hline A. westerdijikia & 0 & $16.6 \pm 0.92^{\mathrm{a}}$ & $13.2 \pm 1.21^{\mathbf{b}}$ & $11.8 \pm 0.86^{\mathbf{c}}$ & $8.4 \pm 0.58^{d}$ & $8.2 \pm 1.04^{\mathrm{d}}$ & 0 \\
\hline F. proliferatum & 0 & $11.5 \pm 0.86^{\mathbf{b}}$ & $16.7 \pm 1.08^{\mathrm{a}}$ & $9.2 \pm 0.58^{c}$ & $8.8 \pm 0.86^{\mathrm{c}}$ & $7.5 \pm 0.50^{\mathrm{d}}$ & 0 \\
\hline F. verticillioides & 0 & $13.5 \pm 0.58^{\mathrm{a}}$ & $10.4 \pm 0.48^{\mathbf{b}}$ & $8.8 \pm 0.28^{c}$ & $8.0 \pm 1.00^{\mathrm{d}}$ & $7.7 \pm 0.48^{d}$ & $7.2 \pm 0.21^{\mathrm{e}}$ \\
\hline P. verrucosum & 0 & $15.8 \pm 1.14^{\mathrm{a}}$ & $14.7 \pm 1.28^{b}$ & $9.6 \pm 1.58^{c}$ & $8.8 \pm 1.14^{\mathrm{d}}$ & $8.2 \pm 0.76^{\mathrm{e}}$ & $8.0 \pm 1.00^{\mathrm{e}}$ \\
\hline
\end{tabular}
$\mathrm{n}=3, *$ S.E: standard error, different subscripts within the row are significantly different at the 5\% level, $0:$ No inhibition, negative control: DMSO, positive control: Nystatin. 
Also, Kerr et al. [46] revealed that Pseudomonas spp. produces a variety of metabolites, of which some exhibit the antimicrobial activity of which antimicrobial substances pyrrolnitrin has been known to possess antifungal activity. Karpagam et al. [13] found that pyocyanin produced by $P$. aeruginosa possesses antifungal activity against Candida albicans, C. krusei, C. glabrata, C. tropicalis and Cryptococcus neoformans. Anjaiah et al. [47] reported that $P$. aeruginosa PNA1 produced phenazine antibiotics, pyocyanin, and phenazine-1-carboxylic acid, when grown in culture and inhibited the mycelial growth of Fusarium oxysporum, Penicillium splendens and other phytopathogenic fungi. Sudhakar et al. [27] indicated that pyocyanin from $P$. aeruginosa WS1 had MIC activity about $64 \mu \mathrm{g} \mathrm{ml}^{-1}$ against Aspergillus flavus and A. fumigatus and $128 \mu \mathrm{g} \mathrm{ml}^{-1}$ against Candida sp.

Hassanein et al. [48] reported that Pseudomonas aeruginosa Sha8 chloroform extract had antifungal activity against Aspergillus niger, Helminthosporium sp., Fusarium oxysporium, Candida albicans, and Saccharomyces cerevisiae. Bakthavatchalu et al. [49] reported that pyocyanin produced by $P$. aeruginosa plays an essential role as an indicator of phytopathogens pathogens like $R$. solani. Jayaseelan et al. [50] found that pyocyanin extract of $P$. aeruginosa was isolated from rhizosphere soil can be used as biosupplement antagonism against fungal rice pathogens such as Helminthosporium oryzae, Pyricularia oryzae and Rhizoctonia solani. Audenaert et al. [51] reported the role of pyocyanin from $P$. aeruginosa 7NSK2 strain, in inducing resistance to Botrytis cinerea that causes infection in tomato and grapevine. Mallesh [52] found that Pseudomonas strains isolated from the rhizosphere plant were used to treat against various species of Fusarium, Ralstonia and Meloidogyne which cause wilting disease in coleus and ashwagandha species. Also, Audenaert et al. [51] reported that pyocyanin from $P$. aeruginosa $7 \mathrm{NSK} 2$ strain-induced resistance to Botrytis cinerea that causes infection in tomato and grapevine.

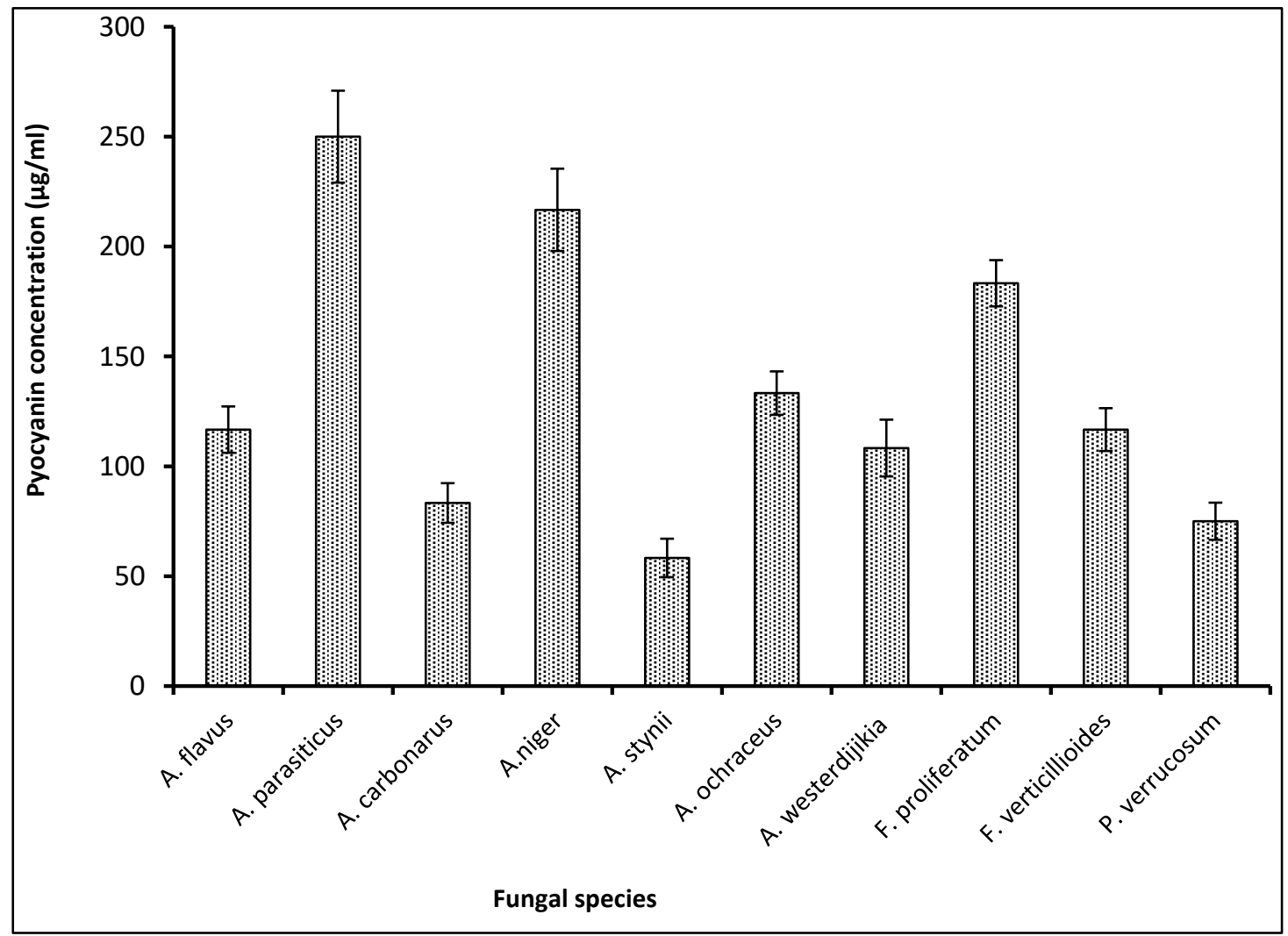

Figure 6. Minimum Inhibitory concentration of pyocyanin against different strains of Mycotoxigenic fungi. 
3.2.4. MIC of pyocyanin against mycotoxigenic fungi.

As shown in Figure (6) the minimum inhibitory concentration of pyocyanin against 10 species of mycotoxigenic fungi. The lowest MIC value of purified pyocyanin $\left(58.3 \mu \mathrm{g} \mathrm{ml}^{-1}\right)$ was observed against $A$. styni followed by $P$. verrucosum and $A$. carbonarus with MIC values 75.0 and $83.3 \mu \mathrm{g} \mathrm{ml}^{-1}$, respectively. Whereas the highest MIC was recorded by A. parasiticus, A. niger, $F$. proliferatum and A. ochraceus with values $250,216.7,183.3$, and $133.3 \mu \mathrm{g} \mathrm{ml}^{-1}$, respectively. Purified pyocyanin recorded the same MIC value $\left(116.7 \mu \mathrm{g} \mathrm{ml}^{-1}\right)$ against both $A$. flavus and F., F. verticillioides, while A. westerdijikia needed $108.3 \mu \mathrm{g} \mathrm{ml}^{-1}$ to observe MIC value by pyocyanin.

Kerr et al. [46] reported that the significant antifungal agent of $P$. aeruginosa was found to be pyocyanin and pyocyanin MICs for Candida albicans and Aspergillus fumigatus were about $64 \mu \mathrm{g} \mathrm{ml}^{-1}$. Also, Sudhakar et al. [27] indicated that pyocyanin from P. aeruginosa WS1 had MIC activity about $64 \mu \mathrm{g} \mathrm{ml}^{-1}$ against Aspergillus flavus and A. fumigatus and $128 \mu \mathrm{g} \mathrm{ml}^{-}$ ${ }^{1}$ against Candida sp. Rane et al. [39] reported that the minimal inhibitory concentration of pyocyanin was $29 \mu \mathrm{g} / \mathrm{ml}$ for Sclerotium rolfsii and also inhibited the growth of phytopathogens such as Aspergillus niger, Fusarium oxysporum, S. rolfsii and Colletotricum falcatum.

\subsection{Toxicity evaluation of pyocyanin.}

\subsubsection{Brine shrimp bioassay.}

The use of aquatic organisms for biomonitoring is an important tool in aquatic ecotoxicology, allowing the detection and evaluation of the potential toxicity [53]. Brine shrimp bioassay was used firstly as an easy test to detect toxicity; however, it is not a specific test. Pyocyanin-induced toxicity on brine shrimp was studied for 12 and 24 hours by exposing 10 brine shrimp larvae to different concentrations of pyocyanin. Percentage mortalities amongst groups of brine shrimp exposed to pyocyanin for 12 and 24 hours are shown in Fig. (7). $\mathrm{LC}_{50}$ values of pyocyanin on brine shrimp nauplii were $368.34 \pm 41.67 \mu \mathrm{g} \mathrm{ml}^{-1}$ and 292.11 $\pm 33.24 \mu \mathrm{g} \mathrm{ml}^{-1}$ for exposure times of 12 and $24 \mathrm{~h}$, respectively. At higher concentrations (500, 750 , and $500 \mu \mathrm{g} \mathrm{ml}^{-1}$ ) within 12 and 24 hours of exposure, the toxicity was $100 \%$, indicating that the toxicity was concentration and time-dependent.

Environmental isolates of $P$. aeruginosa and the inhibitory compound produced by them (pyocyanin) have been accepted as probiotics as well as antagonistic compounds against pathogenic Vibrio spp. in aquaculture [54-56]. The potential degradation and the environmental detoxification of pyocyanin and its precursors have been well reported [57,58]. Yang et al. [59] revealed that phenazine-1-carboxylic acid (PCA) got degraded entirely within 40 hours by soil organism Sphingomonas sp. DP58. However, the pyocyanin induced toxicity is still a controversial issue as the studies have been mainly performed with clinical isolates focusing on its dimensions clinically [10].

Brine shrimp nauplii and shrimp larvae and post-larvae have been used for toxicity assays in a dose-response manner [60, 61]. In literature, no study has ever been reported on the toxicity of pyocyanin on biological systems other than the study conducted by Chythanya et al. [62] on the toxicity of chloroform extract of Pseudomonas 1-2 in P. monodon post-larvae PL-18 and Preetha et al. [56] on in vitro toxicity studies of pyocyanin from Pseudomonas MCCB102 in primary hemocyte culture of P. monodon. 


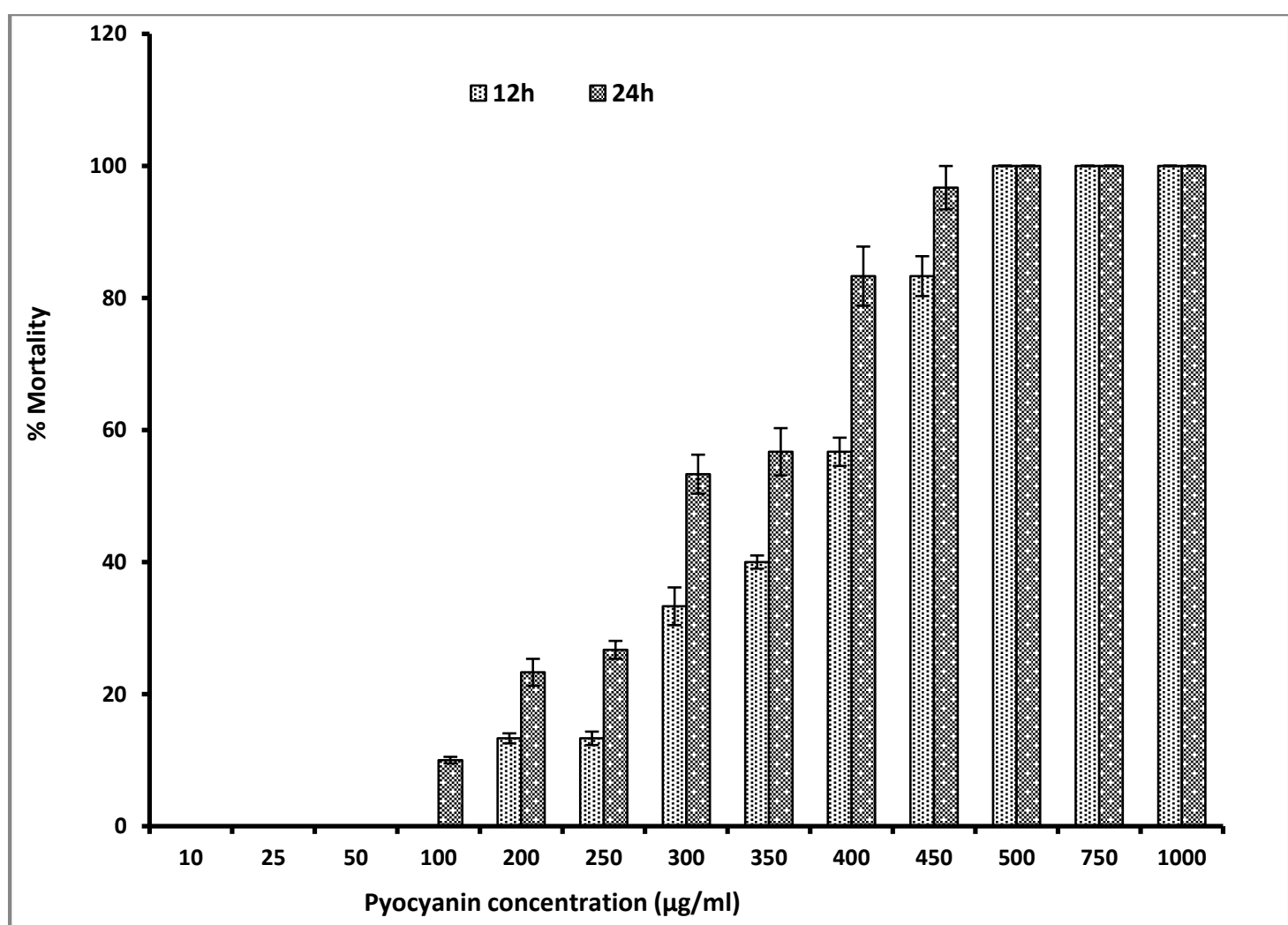

Figure 7. Brine shrimp assay using Artemia salina against pyocyanin.

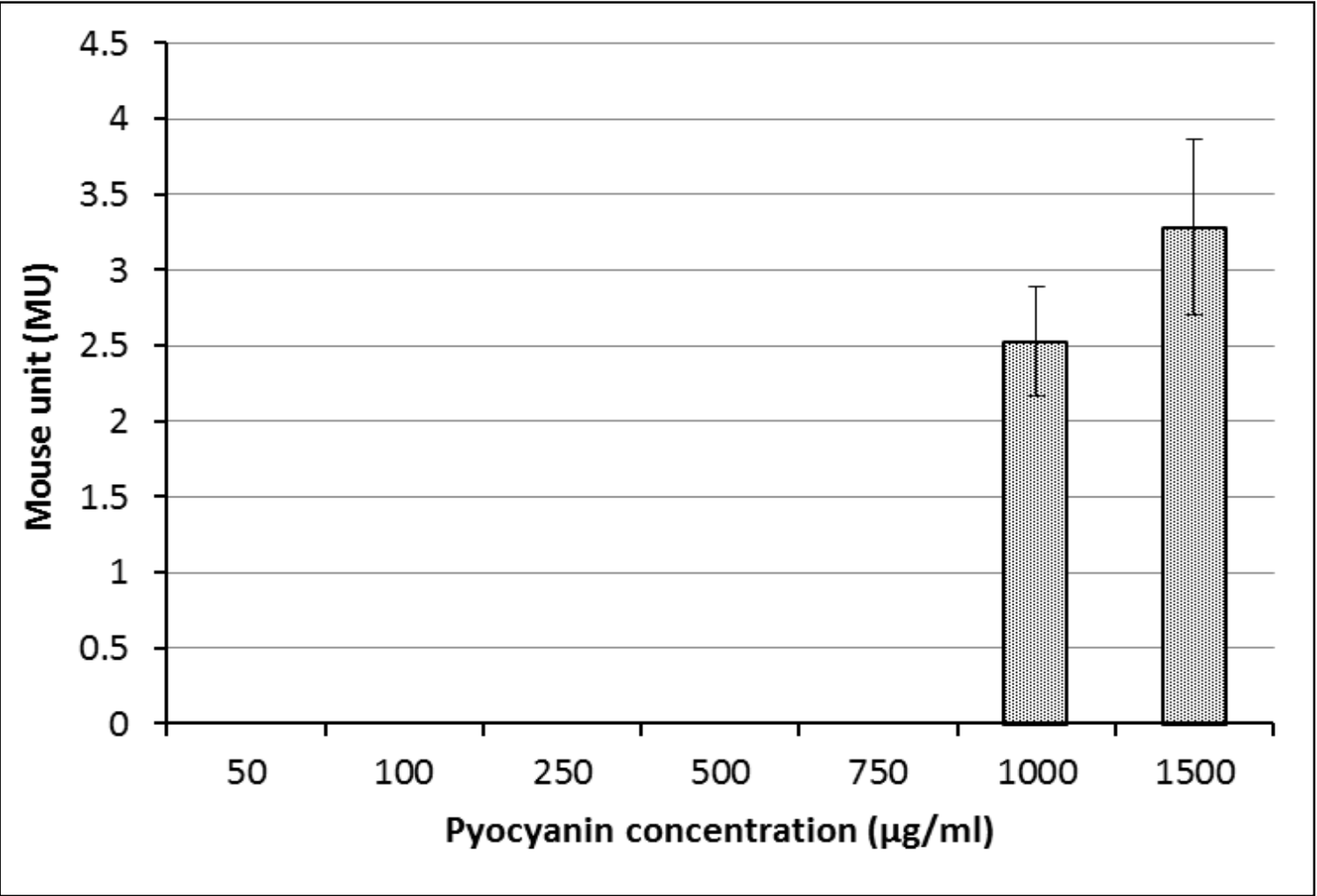

Figure 8. Mouse bioassay of pyocyanin produced by $P$. aeruginosa.

Vijayan et al. [63] studied the pathogenicity of environmental isolates of Pseudomonas PS-102 and reported that it did not cause any lethality to shrimp larvae (Pl-9) upon challenge even at a dosage of $10^{7}$ cells, and a higher $\mathrm{LD}_{50}$ to BALB/c mice $\left(10^{9}\right.$ cells $)$ suggested its safety to the mammalian system. Subsequently, this isolate was deposited with the Culture Collection of National Central for Aquatic Animal, Cochin University of Science and Technology, India, 
as PseudomonasMCCB102, and the same could be used by Preetha et al. [56] and concluded that the inhibitory compound produced by the organism was pyocyanin. In the present study, Pseudomonas MCCB102 has been identified as Pseudomonas aeruginosa. This has been commercialized as the probiotics preparation PS -1TM for shrimp aquaculture systems against pathogenic Vibrio spp.

\subsubsection{Mouse bioassay of pyocyanin.}

The toxicity of pyocyanin was tested using the mouse bioassay technique (Fig. 8). The highest toxicity $2.53 \mathrm{MU}$ (mouse unit) was recorded using purified pyocyanin at a concentration of $1000 \mu \mathrm{g} \mathrm{ml}^{-1}$, and 3.28 MU was observed at a concentration of $1500 \mu \mathrm{g} \mathrm{ml}^{-1}$. On the other hand, there were no toxic effects and symptoms observed in the mice that injected with pyocyanin at the concentration 50,100, 250, 500, and $750 \mu \mathrm{g} \mathrm{ml}^{-1}$ (Figure 8).

\section{Conclusions}

The present study revealed that pyocyanin showed abroad spectrum antimicrobial activity against foodborne pathogenic bacteria and mycotoxigenic fungi. Also, based on the toxicity evaluation, brine shrimp assay, and mouse bioassay, pyocyanin can use food industries application as a promising source in food colorant and food biopreservatives ingredients.

\section{Funding}

This research received no external funding.

\section{Acknowledgments}

This research has no acknowledgment.

\section{Conflicts of Interest}

\section{The authors declare no conflict of interest.}

\section{References}

1. Oladapo A.; Akinyosoye F.; Abiodun O. The Inhibitory effect of different Chemical Food Preservatives on the Growth of Selected Food Borne Pathogenic Bacteria. Afr. J .Microbiol. Res. 2014, 8, 1510-1515, https://doi.org/10.5897/AJMR2013.6370.

2. Marrez, D.; Sultan, Y.; Embaby, M. Biological activity of the cyanobacterium Oscillatoria brevis extracts as a source of nutraceutical and bio-preservative agents. Int. J. Pharmacol. 2017, 13, 1010-1019, https://doi.org/10.3923/ijp.2017.1010.1019.

3. Marrez, D.; Abdelhamid, A.; Darwesh, O. Eco-friendly cellulose acetate green synthesized silver nanocomposite as antibacterial packaging system for food safety. Food Packaging and Shelf Life 2019, 20, https://doi.org/10.1016/j.fpsl.2019.100302.

4. Marrez, D.; Sultan, Y. Antifungal activity of the cyanobacterium Microcystis aeruginosa against mycotoxigenic fungi. J. Appl. Pharm. Sci. 2016, 6, 191-198, https://doi.org/10.7324/japs.2016.601130.

5. Marrez, D.; Naguib, M.; Sultan, Y.; Higazy, A. Antimicrobial and anticancer activities of Scenedesmus obliquus metabolites. Heliyon 2019, 5, https://doi.org/10.1016/j.heliyon.2019.e01404.

6. Marrez D.; Mohamad H. Biological activity and applications of pyocyanin produced by Pseudomonas aeruginosa. Open Access J. Biomed. Sci. 2020, 1, 140-144, https://dx.doi.org/10.38125/OAJBS.000133.

7. Budzikiewicz, H. Secondary metabolites from fluorescent Pseudomonads. FEMS Microbiol. Lett. 1993, 104, 209-228, https://doi.org/10.1111/j.1574-6968.1993.tb05868.x.

8. Meyer, J.; Geoffroy, V.; Baida, N.; Gardan, L.; Izard, D.; Lemanceau, P.; Achouak, W.; Palleroni, N. Siderophore typing, a powerful tool for the identification of fluorescent and nonfluorescent Pseudomonads. Appl. Environ. Microbiol. 2002, 68, 2745-2753, https://doi.org/10.1128/aem.68.6.2745-2753.2002. 
9. Laursen, J.; and Nielsen, J. Phenazine natural products: Biosynthesis, synthetic analogues, and biological activity. Chem. Rev. 2004, 104, 1663-1685, https://doi.org/10.1021/cr020473j.

10. Muller, M.; Li, Z.; Maitz, P. Pseudomonas pyocyanin inhibits wound repair by inducing premature cellular senescence: role for p38 mitogen-activated protein kinase. Burns 2009, 35, 500-508, https://doi.org/10.1016/j.burns.2008.11.010.

11. King, E.; Ward, K.; Raney, D. Two simple media for the demonstration of pyocyanin and fluorescin. J. Lab. Clin. Med. 1954, 44 ,301-307.

12. Ohfuji, K.; Sato, N.; Hamada-Sato, N.; Kobayashi, T.; Imada, C.; Okuma, H.; Watanabe, E. . Construction of a glucose sensor based on a screen-printed electrode and a novel mediator pyocyanin from Pseudomonas aeruginosa. Biosensors and Bioelectronics 2004, 19, 1237-1244, https://doi.org/10.1016/j.bios.2003.11.010.

13. Karpagam, S.; Sudhakar, T.; Lakshmipathy, M. Microbicidal response of pyocyanin produced by $P$. aeruginosa toward clinical Isolates of fungi. Int. J. Pharm. Pharm. Sci. 2013, 5, 870-873.

14. Mullaiselvan, I.; Kanagaraj, V.; Dharmar, B.; Balaraman, M.; Meignanalakshmi, S. Production, characterization and cytotoxic evaluation of pyocyanin pigment extracted from Pseudomonas aeruginosa isolated from industrial soil resources. Int. J. Curr.Microbiol.App.Sci. 2020, 9, 2117-2130, https://doi.org/10.20546/ijcmas.2020.903.242.

15. Bauer, A.; Kirby, W.; Sheriss, J.; Turck, M. Antibiotic susceptibility testing by standardized single method. Am. J. Clin. Pathol. 1966, 45, 493-496.

16. Marrez, D.; El Raey, M.; El-Hagrassi, A.; Seif, M.; Ragab, T.; El Negoumy, S.; Emam, M. Phenolic profile and Antimicrobial activity of Acalypha wilkesiana Seeds Silver nanoparticles Green synthesis against some food borne pathogens. Biosci. Res. 2017, 14, 817-830.

17. Medeiros, M.; Oliveira, D.; Rodrigues, D.; Freitas, D. Prevalence and antimicrobial resistance of Salmonella in chicken carcasses at retail in 15 Brazilian cities. Rev. Panam. Salud. Public. 2011, 30, 555-560, https://doi.org/10.1590/s1020-49892011001200010.

18. Marrez, D.; Abdel-Rahman, G.; Salem, S. Evaluation of Pseudomonas fluorescens extracts as biocontrol agents against some foodborne microorganisms. Jordan J. Biol. Sci. 2019, 12, 535-541.

19. Irith, W.; Kai, H.; Robert E. Agar and broth dilution methods to determine the minimal inhibitory concentration (MIC) of antimicrobial substances. Nat. Protocols. 2008, 3, 163-175, https://doi.org/10.1038/nprot.2007.521.

20. Embaby, M.; El-Raey, M.; Zaineldain, M.; Almaghrabi, O.; Marrez, D. Synergistic effect and efflux pump inhibitory activity of Ficus nitida phenolic extract with tetracycline against some pathogenic bacteria. Toxin Rev. 2019, 39, https://doi.org/10.1080/15569543.2019.1659370.

21. Perrucci, A.; Okmen, A.; Gulluce, M.; Akpulat, H.; Dafera, D. The in vitro antimicrobial and antioxidant activities of the essential oils and methanol extracts of endemic Thymus spathulifolius. Food Contl. 2004, 15, 627-634, https://doi.org/10.1016/j.foodcont.2003.10.005.

22. Meyer, B.; Ferrigni, N.; Putnam, J.; Jacobsen, L.; Nichols, D.; McLaughlin, J. A convenient general bioassay for active plant constituents. Planta Med. 1982, 45, 31-34, https://doi.org/10.1055/s-2007-971236.

23. Marrez, D.; Naguib, M.; Sultan, Y.; Daw, Z.; Zaher, S.; Higazy, A. Phytoplankton profile and toxicity assessment of dominant algal species from different Egyptian aquatic ecosystems. Res. J. Pharm. Biol. Chem. Sci. 2016, 7, 1452-1461.

24. AOAC. Chapter 49-Natural toxins. In: Methods of Analysis. 18 ${ }^{\text {th }}$ ed. Washington, D.C. 2007; pp. 102-166.

25. Parsons, J.; Greenhagen, B.; Shi, K.; Calabrese, K.; Robinson, H.; Ladner J. Structural and functional analysis of the pyocyanin biosynthetic protein PhzM from Pseudomonas aeruginosa. Biochem. 2007, 46, 1821-1828, https://doi.org/10.1021/bi6024403.

26. Priyaja, P. Pyocyanin (5-methyl-1-hydroxyphenazine) produced by Pseudomonas aeruginosa as antagonist to vibrios in aquaculture: over expression, downstream process and toxicity. Ph.D. Thesis, Cochin Univ. Sci. Technol., India. 2012, https://www.researchgate.net/publication/338454130.

27. Sudhakar, T.; Karpagam, S.; Shiyama, S. Analysis of pyocyanin compound and its antagonistic activity against phytopathogens. Int. J. Chem.Tech. Res. 2013, 5, 101-1106.

28. Nansathit, A.; Apipattarakul, S.; Phaosiri, C.; Pongdontri, P.; Chanthai, S.; Ruangviriyachai, C. Synthesis, isolation of phenazine derivatives and their antimicrobial activities. Walailak J. Sci. Tech. 2009, 6, 79-91.

29. Laxmi, M.; Bhat S. Characterization of pyocyanin with radical scavenging \& antibiofilm properties isolated from Pseudomonas aeruginosa strain BTRY1. 3 Biotech. 2016, 6, https://doi.org/10.1007/s13205-015-03501.

30. Ra'oof, W.; Latif, I. In vitro study of the swarming phenomena and antimicrobial activity of pyocyanin produced by Pseudomonas aeruginosa isolated from different human infections. Eur. J. Sci. Res. 2010, 47, 405-421.

31. Narenkumar, J.; Sathishkumar, K..; Sarankumara, R.; Murugan, K.; Rajasekar, A. An anticorrosive study on potential bioactive compound produced by Pseudomonas aeruginosa TBH2 against the biocorrosive bacterial biofilm on copper metal. Journal of Molecular Liquids 2017, 243, 706-713, https://doi.org/10.1016/j.molliq.2017.08.075.

32. Pal, R.; Revathi, R. Susceptibility of yeast to P. aeruginosa. Ind. J. Med. Microbiol. 1998, 16, 72-74. 
33. Raaijmakers, J.; Weller, D.; Thomashow, L. Frequency of antibiotic-producing Pseudomonas sp. in natural environments. Appl. Environ. Microbiol. 1997, 63, 881-887.

34. Priyaja, P., Jayesh, P., Correya, N., Sreelakshmi, B., Sudheer, N.; Philip, R.; ;Singh, I. Antagonistic effect of $P$. aeruginosa isolates from various ecological niches on Vibrio species pathogenic to crustaceans. J. Coastal Life Med. 2014, 2, 76-84.

35. Alzahrani, S.; Alqahtani, F. Pyocyanin pigment extracted from Pseudomonas aeruginosa isolate as antimicrobial agent and textile colorant. Int. J. Sci. Res. 2016, 5, 467-470.

36. El-Shouny, W.; Al-Baidani, A.; Hamza, W. Antimicrobial activity of pyocyanin produced by Pseudomonas aeruginosa isolated from surgical wound-infections. Int. J. Pharma. Med. Sci. 2011, 1, 1-7.

37. Saha, S.; Thavasi, R.; Jayalakshmi, S. Phenazine pigments from Pseudomonas aeruginosa and their application as antibacterial agent and food colourants. Res. J. Microbiol. 2008, 3, 122-128, https://doi.org/10.3923/jm.2008.122.128.

38. Rahman, P.; Pasirayi, G.; Auger, V.; Ali, Z. Development of a simple and low cost microbioreactor for highthroughput bioprocessing. Biotechnol. Lett. 2009, 31, 209-214, https://doi.org/10.1007/s10529-008-9853-8.

39. Rane, M.; Prashant, D.; Bhushan, L.; Sudhir, B. Detection, Isolation and Identification of Phenazine -1Carboxylic acid Produced by Biocontrol Strains of Pseudomonas aeruginosa. J. Sci. Indust. Res. 2007, 66, 627-631.

40. El-Fouly, M.; Sharaf, A.; Shahin, A.; El-Bialy, H.; Omara, A. Biosynthesis of pyocyanin pigment by Pseudomonas aeruginosa. J. Rad. Res. Appl. Sci. 2015, 8, 36-48, http://dx.doi.org/10.1016/j.jrras.2014.10.007.

41. Mathew, A.; Eldo, A.; Molly, A. Production optimization, characterization and antimicrobial activity of pyocyanin from Pseudomonas aeruginosa SPC B 65. BTAIJ 2011, 5, 297-301.

42. Onbasli, D.; Aslim, A. Determination of antimicrobial activity and production of some metabolites by $P$. aeruginosa B1 and B2 in sugar beet molasses. Afr. J. Biotechnol. 2008, 7, 4614-4619.

43. Nowroozi, J.; Sepahi, A.; Rashnonejad, A. Pyocyanine Biosynthetic Genes in Clinical and Environmental Isolates of Pseudomonas aeruginosa and Detection of Pyocyanine's Antimicrobial Effects with or without Colloidal Silver Nanoparticles. Cell J. 2012, 14, 7-18.

44. Wilson, R.; Pitt, T.,; Taylor, G.; Watson, D.; MacDermot, J.; Sykes, D.; Roberts, D.; Cole, P. Pyocyanin and 1-hydroxyphenazine produced by Pseudomonas aeruginosa inhibit the beating of human respiratory cilia in vitro. J. Clin. Invest. 1987, 79, 221-229, https://doi.org/10.1172/JCI112787.

45. Kerr, J. Suppression of fungal growth exhibited by Pseudomonas aeruginosa. J. Clin. Microbiol. 1994, 32 , 525-527.

46. Kerr, J.; Taylor, G.; Rutman, A.; Hoiby, N.; Cole, P.; Wilson R. Pseudomonas aeruginosa pyocyanin and 1hydroxyphenazine inhibit fungal growth. J. Clin. Pathol. 1999, 52, 385-387, https://doi.org/10.1136/jcp.52.5.385.

47. Anjaiah, V.; Koedam, N.; Nowark-Thompson, B.; Loper, J.; Hofte, M.; Tambong J.; Cornelis P. Involvement of phenazines and anthranilate in the antagonism of Pseudomonas aeruginosa PNA1 and Tn5 derivatives toward Fusarium spp. and Pythium spp. Molecular Plant-Microbe Interactions 1998, 11, 847-854, https://doi.org/10.1094/MPMI.1998.11.9.847.

48. Hassanein, W.; Awny, N.; El-Mougith, A.; Salah ElDien, S. The Antagonistic Activities of Some Metabolites produced by Pseudomonas aeruginosa Sha8. J. Appl. Sci. Res. 2009, 5, 404-414.

49. Bakthavatchalu, S.; Shivakumar, S.; Sullia, S. Molecular detection of antibiotic related genes from $P$. aeruginosa FP6, an antagonist towards Rhizoctonia solani and Colletotrichum gloeosporioides. Turk. J. Biol. 2013, 37, 289-295, https://doi.org/10.3906/biy-1207-56.

50. Jayaseelan, S.; Ramaswamy, D.; Dharmaraj, S. Pyocyanin: production, applications, challenges and new insights. World J. Microbiol. Biotechnol. 2014, 30, 1159-1168, https://doi.org/10.1007/s11274-013-1552-5.

51. Audenaert, K.; De Meyer, G.; Höfte, M. Abscisic acid determines basal susceptibility of tomato to Botrytis cinerea and suppresses salicylic acid-dependent signaling mechanisms. Plant Physiol. 2002, 128, 491-501, https://doi.org/10.1104/pp.010605.

52. Mallesh, S. Plant growth promoting rhizobactaria their characterization and mechanism in the suppression of soil borne pathogens of coleus and ashwaghandha. Ph.D. Thesis, University of Agricultural Sciences, Dharwad, India. 2008.

53. U.S. Environmental Protection Agency Technical Support Document for Water Quality-Based Toxic Control, EPA, Washington, DC. 1984; pp. 135.

54. Hai, N.; Buller, N.; Fotedar, R. Effects of probiotics (Pseudomonas synxantha and P. aeruginosa) on the growth, survival and immune parameters of juvenile western king prawns (Penaeus latisulcatus Kishinouye, 1896). Aquac. Res. 2009, 40, 590-602, https://doi.org/10.1111/j.1365-2109.2008.02135.x.

55. Pai, S.; Anas, A.; Jayaprakash, N.; Priyaja, P.; Sreelakshmi, B.; Preetha, R.; Philip, R.; Mohandas, A.; Singh, I. Penaeus monodon larvae can be protected from Vibrio harveyi infection by pre-emptive treatment of a rearing system with antagonistic or non-antagonistic bacterialprobiotics. Aquac. Res. 2010; 41, 847-860, https://doi.org/10.1111/j.1365-2109.2009.02362.x. 
56. Preetha, R.; Jose, S.; Prathapan, S.; Vijayan, K.; Jayaprakash, N.; Philip, R., Bright Singh, I. An inhibitory compound produced by Pseudomonas with effectiveness on Vibrio harveyi. Aquac Res. 2010, 41, 1452-1461, https://doi.org/10.1111/j.1365-2109.2009.02436.X.

57. Chen, K.; Hu, H.; Wang, W.; Zhang, X.; Xu, Y. Metabolic degradation of phenazine-1-carboxylic acid by the strain Sphingomonas sp. DP58: Then identification of two metabolites. Biodegradation 2008, 19, 659667, https://doi.org/10.1007/s10532-007-9171-1.

58. Reszka, K.; O'Malley, Y.; McCormick, M.; Denning, G.; Britigan, B. Oxidation of pyocyanin, a cytotoxic product from Pseudomonas aeruginosa, by microperoxidase 11 and hydrogen peroxide. Free Rad. Biol. Med. 2004, 36, 1448-1459, https://doi.org/10.1016/j.freeradbiomed.2004.03.011.

59. Yang, Z.; Wang, W.; Jin, Y.; Hu, H.; Zhang, X., Xu, Y. Isolation, identification, and degradation characteristics of phenazine-1- carboxylic acid degrading strain Sphingomonas sp. DP58. Curr. Microbiol. 2007, 55, 284-287, https://doi.org/10.1007/s00284-006-0522-7.

60. Vinayak, R.; Sabu, A.; Chatterji, A. Bio-prospecting of a few brown seaweeds for their cytotoxic and antioxidant activities. Evidence-Based Compl. Alter. Med. 2011, 2011, 1-9, https://doi.org/10.1093/ecam/neq024.

61. Darwesh, O.M.; Barakat, K.M.; Mattar, M.Z.; Sabae, S.Z.; Hassan, S.H. Production of antimicrobial blue green pigment Pyocyanin by marine Pseudomonas aeruginosa. Biointerface Research in Applied Chemistry 2019, 9, 4334 - 4339, https://doi.org/10.33263/BRIAC95.334339.

62. Chythanya, R.; Karunasagar, I.; Karunasagar, I. Inhibition of shrimp pathogenic vibrios by a marine Pseudomonas I-2 strain. Aquacult. 2002, 208, 1-10, https://doi.org/10.1016/S0044-8486(01)00714-1.

63. Vijayan, K.; Singh, I.; Jayaprakash, N.; Alavandim, S.; Pai, S.; Preetha, R.; Rajan, J.; Santiago, T. A brackish water isolate of Pseudomonas PS-102, a potential antagonistic bacterium against pathogenic vibrios in penaied and nonpenaied rearing systems. Aquacult. 2006, 251, 192-200, https://doi.org/10.1016/j.aquaculture.2005.10.010. 